особливість у сприйманні художніх смислів музичних творів, що відображають культурну традицію історичної епохи, у якій жив композитор, його внутрішній світ. У музичних творах художні смисли є непредметним i, водночас, поетичними. Уміння розкодувати художні смисли, з дотриманням певної об'єктивності, формуються тільки в контексті культурного досвіду тієї епохи, у якій творив композитор.

Отже, аналіз науково-теоретичного досвіду надав змогу визначити сутність базових понять дослідження: культура, культурологія, культурологічний підхід, культурологічна підготовка, педагогічна культура. Застосування культурологічного підходу до професійної підготовки майбутніх учителів музичного мистецтва має свою специфіку, що полягає в: опануванні студентами культурним досвідом різних видів мистецтв; привласненні цінностей мистецтв, значною мірою, через почуттєву сферу; сприйманні художніх смислів музичних творів. Культурологічна підготовка надає змогу сформувати ціннісну сферу майбутніх фахівців та сприяти зростанню їх духовних потреб.

\title{
Література
}

1. Сучасний словник-мінімум іншомовних слів / уклали : О. Скопненко, Т. Цимбалюк. - К. : Довіра, 2008. - 798 с. 2. Український педагогічний словник / упоряд. С. У. Гончаренко. - К. : Либідь, 1997. - 376 с. 3. Ключевский В. Лекции по русской истории: 8 т. / В. Ключевский. - М. : Гос. изд-во полит. лит-ры, 1956. - 328 с. 4. Флоренский П. Иконостас / П. Флоренский. // Христианство и культура. - М. : Фолио, 2001. - С. 521-626. 5. Лихачев Д. Поэтика древнерусской культуры / Д. Лихачев. - М. : Наука, 1979. - 360 с. 6. Кармин А. С. Культурология / А. С. Кармин, Е. С. Новикова. СПб. : Питер, 2004. - 464 с. 7. Зязюн І. А. Освітній простір культури в педагогічній теорії / I. А. Зязюн // Kstafcene zawodowe: pedagogika i psihologia - Професйна освіта: педагогіка і психологія: пол.-укр. журнал / за ред. Т. Левовицького, І. Вільш, І. Зязюна, Н. Ничкало. - Ченхстохова; К., 2005. Вип. УІІ. - С. 35-46. 8. Сисосва С. О. Розвиток освіти в умовах полікультурного глобалізованого світу / С. О. Сисоєва // Проблеми полікультурності у неперервній професійній освіті: наукове видання; за ред. К. В. Балабанова, С. О. Сисоєвої, І. В. Соколової. - Маріуполь : Ноулідж, 2001. С. 11-18. 9. Иванова Т. В. Культурологическая подготовка будущого учителя: [монографія] / Т. В. Иванова. - К. : ЦВП, 2005. - 282 с. 10. Сухомлинский В. А. Как любить детей // Избранные произведения: в 5-ти т. / В. А. Сухомлинский. - К., 1980., - Т. 5. - С. 427-668. 11. Рудницька О. П. Музика і культура особистості: проблеми сучасної освіти: [навч. посіб.] / О. П. Рудницька. - К. : ІЗМН, 1998. - 248 с. 12. Падалка Г. М. Педагогіка мистецтва (Теорія і методика викладання мистецьких дисциплін) / Г. М. Падалка. - К. : Освіта України, 2010. - 274 с. 13. Масол Л. М. Концепція художньо-естетичного виховання учнів у загальноосвітніх навчальних закладах України / Л. М. Масол // Шкільний світ. - 2002. - № 9. - С. 1-6.

\section{ФОРМУВАННЯ ТВОРЧОЇ КОМПЕТЕНТНОСТІ МАЙБУТНІХ УЧИТЕЛІВ ІНОЗЕМНОЇ МОВИ У ПРОЦЕСІ ЇХ ФАХОВОЇ ПІДГОТОВКИ}

Пахомова О. В. Формування творчої компетентності майбутніх учителів іноземної мови у процесі їх фахової підготовки.

У статті розкрито сутність поняття «творча компетентність», визначено структуру й схарактеризовано компоненти фахової підготовки майбутніх учителів іноземної мови, розглянуто підходи та шляхи формування творчої компетентності студентів у процесі їх фахової підготовки.

Ключові слова: творча компетентність майбутніх учителів іноземної мови, фахова підготовка, компетентнісний підхід, компетенція.

Пахомова Е. В. Формирование творческой компетентности будущих учителей иностранного языка в процессе их профессиональной подготовки.

В статье раскрывается суть понятия «творческая компетентность», определяется структура и характеризуются компоненты профессиональной подготовки будущих учителей иностранного языка, рассматриваются подходы и способы формирования творческой компетентности студентов в процессе их профессиональной подготовки.

Ключевые слова: творческая компетентность будущих учителей иностранного языка, профессиональная подготовка, компетентностный подход, компетенция. 
Pahomova E. V. The formation of the creative competence of future foreign language teachers in the process of their professional training.

The article reveals the essence of the concept «creative competence», defines the structure and points out the components of professional training of future foreign language teachers, considers the approaches and ways of forming students' creative competence during their professional training.

Key words: creative competence of future foreign language teachers, professional training, competence approach, competency.

Успішне розв'язання завдань сучасної професійної освіти безпосередньо пов'язане 3 удосконаленням підготовки майбутніх учителів загалом та вчителів іноземної мови зокрема. У зв'язку з цим метою вищих навчальних закладів, спрямованих на професійну підготовку майбутніх учителів іноземної мови, $\epsilon$ створення оптимальних умов, що сприятимуть професійному становленню та зростанню висококваліфікованих фахівців із високим рівнем готовності до творчого виконання професійної діяльності і творчим потенціалом.

Актуальність проблеми формування творчої компетентності майбутніх учителів іноземної мови у процесі фахової підготовки зумовлена значними змінами в сучасній освітній парадигмі та новими вимогами суспільства до рівня фахової підготовки майбутніх учителів іноземної мови.

Творчість завжди була й залишається предметом багатьох дослідження в галузі філософії, психології та педагогіки. 3-поміж науковців, які опікувалися цією проблемою, варто назвати: В. Андреєва, М. Бердяєва, В. Бехтерєва, Л. Виготського, І. Волкова, А. Спіркіна, С. Сисоєва. Психологічні аспекти творчого розвитку особистості розглядаються у працях Н. Бібік, М. Свтуха, А. Кузьмінського, О. Овчарук, О. Пометун. Творчість як механізм розвитку особистості досліджувалась в доробках В. Кудрявцева, Я. Пономарьова; проблема педагогічної творчості вивчається В. Загвязинським, В. Кан-Каликом, М. Поташником.

Проблемам формування творчої особистості студентів у процесі їхньої фахової підготовки присвячено роботи А. Данилової, С. Зинов'єва, Н. Кузьміної, М. Лазарева, Н. Федоренко, Н. Черкасова, В. Цибульської. В. Мадзігон та А. Хуторський досліджують креативну освітню концепцію. О. Киричук, Н. Кічук, М. Нікандров, В. Сластьонін, Г. Чижиков вивчають проблему формування креативного потенціалу молодого спеціаліста як основи успішної педагогічної діяльності. Закладені в цих дослідженнях положення та висновки стали основою подальшого розроблення проблеми формування творчої особистості майбутніх учителів іноземної мови у процесі професійної підготовки.

Незважаючи на достатню розробленість загалом проблеми формування творчої особистості людини та майбутніх фахівців, проблема формування творчої компетентності майбутніх учителів іноземної мови у процесі фахової підготовки не знайшла глибокого вивчення в сучасній науковій та методичній літературі, що зумовило необхідність дослідження саме цього аспекту проблеми.

Метою статті є спроба виокремити основні підходи та шляхи до розв'язання проблеми формування творчої компетентності майбутніх учителів іноземної мови у процесі їх фахової підготовки.

У процесі нашого теоретичного дослідження проблеми формування творчої компетентності майбутніх учителів іноземної мови під час їх фахової підготовки нами 3'ясовано, що творча компетентність майбутніх учителів іноземної мови характеризується такими ознаками, як:

- гнучкість та мобільність знань, поведінки, соціальних ролей;

- відкритість новому, адаптивність;

- здатність до інноваційної діяльності;

- готовність до педагогічної творчості (здатність до творчості у розв'язанні професійних задач) [1, с. 235].

Сутність творчої компетентності майбутніх учителів іноземної мови передбачає відмову від прямого копіювання як чужого, так і власного сталого досвіду, норм та зразків, свободу від стереотипів, указівок та настанов. Отже, творча компетентність майбутніх учителів іноземної мови реалізується насамперед у потребі у самовдосконаленні майбутнього вчителя, здатності до самоактуалізації у професії та пошуку індивідуального стилю педагогічної та методичної діяльності [3, с. 55]. 
Розмаїття педагогічних ситуацій, неповна відповідність педагогічних завдань типовим прийомам педагогічної діяльності, недостатність методичного досвіду об'єктивно стимулюють майбутніх учителів іноземної мови до набуття досвіду творчості у трьох галузях:

- професійно-педагогічній діяльності (пошук нових способів вивчення учнів, створення та застосування нових діагностичних прийомів, творче поєднання сучасних методів та прийомів навчання іноземної мови у власній практиці навчальної діяльності, формування власного стилю навчально-виховної діяльності, творче поєднання методів навчання, виховання й організації);

- педагогічному спілкуванні та комунікативній творчості (пошук та знаходження нових комунікативних задач, засобів мобілізації міжособового спілкування та взаємодії між учнями, створення нових форм спілкування у груповій, фронтальній та індивідуальній роботі з учнями);

- сфері власної професійної компетентності (пошук шляхів самореалізації та самовдосконалення на основі самоусвідомлення власної творчої індивідуальності, визначення індивідуальних шляхів власного професійного становлення та розвитку, побудови плану формування та подальшого розвитку професійної компетентності) [1, с. 235-236 ].

Процес формування творчої компетентності $\epsilon$ доволі складним, його успішність визначається тим, наскільки в умовах вищої школи вдасться розв'язання таких задач:

- спрямувати педагогічний процес на розвиток творчої особистості майбутнього вчителя, зорієнтувати його на усвідомлення цінності власної особистості та професійної компетентності;

- використати всі структурні компоненти вишівської підготовки, у змісті якої важливе місце належить фаховій підготовці;

- конкретизувати сутність, зміст, навчальні технології, які передбачають особистіснодіяльнісний і компетентнісний підходи до ії організації;

- максимально використати виховні та навчальні функції педагогічної теорії та практичної діяльності у формуванні творчої компетентності у процесі вивчення фахових дисциплін, у самостійній та навчально-дослідній роботі з методики, в організації педагогічної практики студентів.

Розв'язання означених вище задач неможливе без визначення ролі кожного структурного компонента всієї системи вишівської підготовки та передовсім ії фахового складника.

У структурі фахової підготовки виокремлюють теоретичну підготовку, самостійну навчально-дослідну роботу та педагогічну практику. Ї̈̈ значення полягає в тому, щоб забезпечити кожному студентові «високий професіоналізм, інноваційний стиль науковопедагогічного мислення, готовність до створення нових цінностей та прийняття творчих рішень, стимулювати в кожного студента безперервний пошук нестандартних дій, потребу в постійній самоосвіті та готовності до неї, перспективу у своєму науковому, духовному, ідейному рості, професійній працездатності» [1, с. 4].

Система фахової підготовки майбутніх учителів іноземної мови має грунтуватися на принципах особистісної спрямованості, активної діяльності, педагогічної взаємодії. Реалізація цілей та задач фахової підготовки відбувається у взаємозв'язку різних форм організації навчально-виховного процесу, таких, як лекції, семінарські та лабораторно-практичні заняття, індивідуальні заняття, консультації та педпрактика. Вони покликані створити гармонійне поєднання всіх компонентів фахової підготовки та спрямовані на розвиток творчої компетентності майбутніх учителів іноземної мови як складників їх професійної компетентності.

У програмних документах, науковій літературі декларується зв'язок теорії та практики, практико-орієнтований характер фахової підготовки, насправді підручники, навчальні посібники загалом містять завдання репродуктивного характеру. Доволі обмежено представлено завдання синтетично-творчого та творчого характеру. Майже єдиний вид творчого завдання - захист проектів, містить можливі теми, та до нього не додається опис, що собою становить цей проект, немає методики його виконання. Завдання для самостійної роботи студентів містять загалом самостійне опрацювання теоретичних розділів курсу, написання рефератів, підготовку доповідей. Означені недоліки не сприяють формуванню у студентів необхідних фахових умінь та навичок професійної діяльності, не вчать творчого мислення та відповідно не сприяють формуванню творчої компетентності.

Науково-дослідний складник фахової підготовки представлений у формі написання курсових та кваліфікаційних робіт із методики викладання іноземної мови, залучення студентів 
до роботи в наукових проблемних групах під керівництвом викладачів фахових дисциплін. Науково-дослідна робота має спрямовуватися на формування та розвиток умінь науководослідної роботи та передбачає: набуття вмінь та навичок самостійного пошуку інформації, формування вмінь користування науково-технічними засобами, умінь аналізувати, систематизувати, узагальнювати набуту інформацію, робити висновок, оволодіння методиками, методами, прийомами та засобами науково-педагогічних досліджень.

За навчальним планом написання курсових робіт виконується студентами у 7 семестрі, до проходження ними виробничої педагогічної практики. На нашу думку, такий порядок організації фахової підготовки унеможливлює виконання студентами науково-дослідної роботи, оскільки студенти хоча й мають досвід початкового ознайомлення з педагогічним процесом та практикою шкільної роботи, яку вони отримують на пасивній навчальній практиці у 4 семестрі, але не $\epsilon$ готовими до виконання такого доволі складного виду наукової діяльності, яким є написання курсової роботи. Усе це призводить до втрати системності та послідовності у процесі фахової підготовки, набуття нею формального абстрактного характеру, не сприяє усвідомленню студентами важливості та значення науково-дослідної діяльності для формування власної професійної і творчої компетентності.

Підвищення результативності фахової підготовки у формуванні творчої компетентності майбутніх учителів іноземної мови пов'язано з: особистісно-гуманістичною спрямованістю всієї системи; формуванням усіх структурних компонентів, що розкривають зміст професійної та творчої компетентності майбутніх вчителів; сприянням формуванню творчих якостей студентів у іiі процесі; систематичним моніторингом, контролем, самоконтролем та самооцінкою навчальних досягнень і результатів професійного росту студентів.

Ефективність формування творчої компетентності майбутніх учителів іноземної мови в процесі їх фахової підготовки зумовлена виявленням дидактичних умов та подоланням суперечностей між вимогами, що висуваються до особистості та діяльності майбутнього вчителя та фактичним рівнем творчої компетентності, між типовою системою фахової підготовки та особистісною сутністю творчої компетентності. Стан досліджуваної проблеми формування творчої компетентності майбутніх учителів іноземної мови вимагає подальших наукових пошуків. Детального розгляду потребують: методики діагностування рівня сформованості творчої компетентності майбутнього вчителя, показників та критеріїв ії сформованості, розроблення моделі та технології ії формування.

\section{Література}

1. Ніцой А. І. 3 досвіду підготовки вчителя в сучасних умовах / А. І. Ніцой // Вопросы научной и профессионально-педагогической подготовки учителя. - Херсон : ХПИ им. Н. К. Крупской, 1991. С. 3-6. 2. Пахомова О. В. Креативність як ознака професійної компетентності майбутніх учителів іноземної мови / О. В. Пахомова // Теорія і практика проектування авторських педагогічних систем: [зб. матеріалів всеукр. науково-практ. конференції]. - К. : Інститут обдарованої дитини НАПН України, 2012. - С. 239-243. 3. Пахомова О. В. Проблема формування творчої компетентності майбутніх учителів іноземної мови в науковій літературі / О. В. Пахомова // Вища освіта України. Додаток 1 до вип. 27. Том II (35). - К. : Гнозис, 2012. - Тематичний випуск «Вища освіта України у контексті інтеграції до європейського освітнього простору». - С. 215-221. 4. Пахомова О.В. Формування професійної компетентності майбутніх учителів філологічних дисциплін у процесі загальнопедагогічної підготовки: дис. ... канд. пед. наук: 13.00 .04 / О. В. Пахомова. - Кіровоград; Кіровоградський державний пед. університет ім. В. Винниченка, 2011. - 264 с.

\section{РОБОЧИЙ ЗОШИТ ЯК ДИДАКТИЧНИЙ ЗАСІБ ПІДГОТОВКИ МАЙБУТНІХ УЧИТЕЛІВ ДО РЕАЛІЗАЦІЇ ДИФЕРЕНЦЙОВАНОГО ПІДХОДУ В НАВЧАННІ МОЛОДШИХ ШКОЛЯРІВ}

Прокоф’єва М. Ю. Робочий зошит як дидактичний засіб підготовки майбутніх учителів до реалізації диференційованого підходу в навчанні молодших школярів.

У статті розглядається робочий зошит як важливий предметно-знаковий засіб навчання, що отримав загальне визнання у викладачів і студентів. Навчальна діяльність у ньому спеціально конструюється і відбивається в певній логіці. Використання робочого зошита полегшує 